\title{
OBLIQUE INTENT, FORESIGHT AND AUTHORISATION
}

\author{
Beatrice Krebs*
}

Abstract: In $R v$ Jogee, the Supreme Court of the United Kingdom (UKSC) abolished a contentious doctrine of criminal law which allowed accomplices to a crime A to be convicted of another's crime B on the basis that they foresaw commission of the latter in the course of the former. The Court held that nothing short of an intention to assist or encourage crime B would suffice to fix the accomplice with criminal liability. At common law intention has traditionally been understood to entail acts and consequences that were either achieved with purpose (direct intent) or foreseen as virtually certain to follow one's chosen course of conduct (oblique intent). This paper argues that Jogee calls into question the continued existence of this latter type of intent, first, as a conceptually distinct species of intent that is, secondly, based on the idea that criminal intents are best measured in degrees of cognition rather than volition. It concludes that the law of secondary liability appears to be edging towards a conception of intent that ultimately depends on whether the accused had endorsed the consequences of his and the perpetrator's actions.

\section{A. INTRODUCTION}

Most legal systems accept that there are two ways in which an individual can become involved in criminal wrongdoing. This reflects gradations of moral responsibility between those who act and those who facilitate or otherwise support the acts of others. ${ }^{1}$ The first is by intentionally committing a crime. Such a person is commonly referred to as the perpetrator or principal offender. The second is by intentionally assisting or encouraging someone else to commit a crime. Such a person is called an accessory or secondary party. Until February 2016, English law recognised a further way in which an individual could become complicit in another's wrongdoing. This was known as parasitic accessory liability (PAL). ${ }^{2}$ As the name suggests, under PAL, liability for one crime was parasitic upon participation in another: 'if two people set out to commit an offence (crime A), and in the course of that joint enterprise one of them (D1) commits another offence (crime B), the second person (D2) is guilty as an accessory to crime B if he had foreseen the possibility that D1 might act as he did'. ${ }^{3}$ This mode of liability differed from ordinary accessory liability - that is the intentional assisting or encouraging of another's criminal actions - in that it neither required the secondary

\footnotetext{
* Associate Professor in Criminal Law, University of Reading.

${ }^{1}$ See John Gardner, 'Complicity and causality' (2007) 1(2) Criminal Law and Philosophy 127.

2 The term was coined by Professor Sir John Smith, 'Criminal liability of accessories: law and law reform' (1997) 113 LQR 453.

${ }^{3} R v$ Jogee [2016] UKSC 8, [2017] AC 387, [2] with reference to Chan Wing-Siu v The Queen [1985] AC $168(\mathrm{PC})$.
} 
party to have positively supported crime $B$, nor for him to have acted with intention to assist or encourage crime B. Participation in crime A with foresight that crime B might be committed on the same occasion was sufficient to convict individuals of crime B under this approach which, in one form or other, continues to exist in other common law jurisdictions. ${ }^{4}$

Some commentators have sought to defend this principle on the basis of a 'change of normative position' 5 argument, according to which the initial embarkation on a joint criminal enterprise (crime A) involves a distinctive normative wrong: by signing up to the criminal venture referred to as crime A, the accessory has changed his position vis-à-vis the legal order. From that point onwards, attendant risks (such as that others involved in the enterprise may commit further offences on the occasion), if foreseen, ${ }^{6}$ will be attributed to the accessory because 'her new status has moral significance: she associates herself with the conduct of the other members of the group... As such, joint enterprise doctrines impose a form of collective responsibility, predicated on membership of the unlawful concert. ${ }^{97}$ This rationale was implicitly rejected, when, in $R v$ Jogee, the Supreme Court of the United Kingdom abolished PAL. Lord Toulson and Lord Hughes (with whom the other three Justices hearing the appeal agreed) left no doubt that they considered the doctrine to be unjustifiable in principle when they asserted that 'we do not consider that [PAL] can be supported, except on the basis that it has been decided and followed at the highest level.' 8

One reason that PAL survived this long was that it facilitated convicting gang members and other participants of group violence when it could not be proved which of them had dealt the fatal blow. The Supreme Court sought to alleviate concerns that Jogee would undermine the fight against gang crime by stressing the concept of conditional intent. Thus, while Jogee has been credited with reforming the English law of complicity, the decision also challenges the common law's conception of intent, as this paper will argue. I do not mean by this that Jogee has "introduced' ${ }^{9}$ the idea of

\footnotetext{
${ }^{4}$ The High Court of Australia re-affirmed their variant of PAL (Miller v The Queen [2016] HCA 30) in the wake of Jogee, as did the Court of Final Appeal for Hong Kong (Hong Kong Special Administrative Region v Chan Kam Shing [2016] HKCFA 87) and the Supreme Court of New Zealand (Uhrle v The Queen [2016] NZSC 64).

${ }^{5}$ See AP Simester, 'The mental element in complicity' (2006) 122 LQR 578, 598.

${ }^{6}$ The foresight criterion did little to narrow down the scope of the attributable risks.

${ }^{7}$ Simester (n 5) 596-597. See also AP Simester, 'Accessory Liability and common unlawful purpose' (2017) 133 LQR 73.

${ }^{8}$ Jogee (n 3) [79].

9 John Child, 'Understanding ulterior mens rea: future conduct intention is conditional intention' (2017) CLJ 311, 316.
} 
conditional intents into the law of complicity. That idea is not new at all. Ultimately all intents are conditional: no one ever intends to do something come what may, ${ }^{10}$ and by extension, no one ever intends to support someone else in doing something come what may. In this sense, conditional intent has always been part and parcel of the very notion of intent, whether in complicity or other contexts. What I do mean is that Jogee calls into question the conventional wisdom on what it means legally to intend a particular outcome in the first place.

Intention as a legal concept has traditionally been seen as encompassing two types of intent, known as direct and 'oblique' (or indirect) intent respectively. Direct intent requires volition at its highest: in the eyes of the law, a consequence is directly intended if the offender acted in order to bring it about. ${ }^{11}$ Oblique intent, by contrast, is a cognitivist concept: a consequence counts as obliquely intended if the offender acted with awareness that it was virtually certain to arise from his chosen course of conduct. In this paper, I will argue that Jogee calls into question the continued existence of this latter type of intent, first, as a conceptually distinct species of intent that is, secondly, based on the idea that criminal intents are best measured in degrees of cognition rather than volition. ${ }^{12}$

My argument proceeds in two steps: first, I will explain how Jogee sides with what has come to be known as the 'Inference View' of intention, thereby rejecting its rival, the so-called 'Identity View'. ${ }^{13}$ The former sees intention as separate from foresight, but acknowledges that foresight can be - sometimes powerful - evidence from which the jury might infer intention. The latter, in contrast, equates foresight with intention. In rejecting this latter view, Jogee has realigned the law of complicity with the general law of murder, although differences persist concerning the threshold condition that makes an inference from foresight to intention permissible in either context. Second, once we accept with Jogee that foresight (in a specified degree) does not equate to intention (contrary to the 'Identity View') but rather constitutes evidence from which intention can be inferred ('Inference View'), the question arises what else

\footnotetext{
${ }^{10}$ Gregory Klass, ‘A conditional intent to perform' (2009) 15 Legal Theory 107, 107-108.

${ }^{11} R v$ Mohan [1976] QB 1 (CA).

${ }^{12}$ A similar argument has been defended by Antje Pedain concerning the meaning of intention in the context of murder and sole perpetrators, see: Antje Pedain, 'Intention and the terrorist example' (2003) Crim LR 579.

${ }^{13}$ I am adopting the terminology used by M. Cathleen Kaveny, 'Inferring intention from foresight' (2004) 120 LQR 81-107. A further discussion and explanation of the Inference and Identity Views is contained in Section C.
} 
jurors might look for in drawing conclusions about a defendant's mental state. It is here that Jogee has arguably opened the door for developing the common law in line with philosophical accounts that locate the reprehensible nature of illicit intents in the actor's attitude towards foreseen acts and consequences, by keeping alive (just about) the idea that an accessory's intention (to assist or encourage another's crime) can be rationalised in terms of authorisation. ${ }^{14}$ I will conclude that in doing so, Jogee lends support to the view that there is but one common concept of legal intention, which is informed by whether an individual has endorsed (in a specified degree, such as 'with purpose') the prohibited act or consequence. ${ }^{15}$

The discussion proceeds as follows: section B gives an account of the facts and a brief summary of the decision in Jogee. The paper then examines the competing views of intention by reference to the relevant case law in the sole offender context (Section C) and complicity (Section D). After some prevarication, the law now appears to subscribe to the 'Inference View' in both contexts, but, as developed in Section E, adopts different threshold conditions. This creates the conundrum that an accessory is still more easily convicted than the person who actually wielded the weapon or struck the fatal blow. Section F puts forward a possible solution, namely a perception of intention as on a spectrum of endorsement which would unify both these strands. Section $\mathrm{G}$ provides a brief conclusion.

\section{B. $R$ V JOGEE}

When, in October 2015, the case of Ameen Jogee reached the UK Supreme Court (UKSC), the parasitic variant of accessory liability was well established in criminal law practice but notorious for having occasioned a high number of appeals. Mr Jogee sought to appeal his conviction for murder. The facts of his case were unusual in that they could have been resolved by ordinary, rather than parasitic, accessory liability. However (presumably) since it was generally considered easier to secure guilty verdicts

\footnotetext{
14 Jogee (n 3) [66]: 'Nor can authorisation of crime B automatically be inferred from continued participation in crime A with foresight of crime B. As Lord Brown accurately pointed out in R v Rahman at para 63, the rule in Chan Wing-Siu makes guilty those who foresee crime B but never intended it or wanted it to happen. There can be no doubt that if D2 continues to participate in crime A with foresight that D1 may commit crime $\mathrm{B}$, that is evidence, and sometimes powerful evidence, of an intent to assist D1 in crime B. But it is evidence of such intent (or, if one likes, of "authorisation"), not conclusive of it.'

${ }^{15}$ Before Jogee, the case for such a common conception of intention was forcefully and convincingly made by Pedain (n 12).
} 
on the basis of what the defendant foresaw than what he intended, ${ }^{16}$ the prosecution decided to seek Mr Jogee's conviction by means of PAL.

Mr Jogee and Mr Hirsi had spent the evening of the murder at their friend Miss Reid's house, consuming drugs and alcohol. There was talk of stabbing someone, and Mr Jogee was seen 'fooling around' with one of Miss Reid's kitchen knives. Eventually Miss Reid sent them away, but a short while later Mr Hirsi returned with Mr Jogee, whom he left waiting outside the house. Back inside the house, Mr Hirsi got into an argument with Mr Fyfe, Miss Reid's partner, who had arrived in the meantime. When Mr Fyfe went upstairs to change his clothes, Mr Hirsi went into the kitchen. He came out with the knife Mr Jogee had been playing with earlier that night. When Mr Fyfe returned, their argument resumed, culminating in Mr Hirsi’s stabbing Mr Fyfe, just once but with fatal consequences. All the while, Mr Jogee had been standing outside on the driveway, damaging Mr Fyfe's car. At one point he had come to the doorway with a bottle in his hand, shouting that 'he wanted to smash it over [Mr Fyfe's] head'. So, when Mr Hirsi murdered Mr Fyfe, had Mr Jogee been an accessory to this crime?

The prosecution charged Mr Jogee with murder on the basis of PAL. To recap, under this doctrine, 'participation in a joint criminal enterprise with foresight or contemplation of an act as a possible incident of that enterprise is sufficient to impose criminal liability for that act carried out by another participant in the enterprise.' ${ }^{17}$ Although the prosecution never clearly said what crime A Mr Jogee was accused of having assisted or encouraged, we can assume that he was being blamed for having encouraged Mr Hirsi's confrontation with Mr Fyfe, which in legal terms amounted to an assault. Consistent with this theory, the jury was invited to find Mr Jogee guilty of murder on the basis that he had encouraged Mr Hirsi's confronting Mr Fyfe with foresight that Mr Hirsi might get hold of the knife which he knew was located in the nearby kitchen and use it at some point to hurt Mr Fyfe with intent to cause him grievous bodily harm, i.e. really serious injury (which in England and Wales suffices for a murder charge, should the injury result in death). The jury found him guilty, applying the foresight test set out by the judge in his summing-up. This had faithfully followed

\footnotetext{
${ }^{16}$ Notwithstanding the fact that, as Kaveny (n 13) 94-95 has convincingly argued, the determination of the defendant's 'foresight requires numerous other determinations, including those regarding the immediate purposes of his action. The materials--data, insights, and inferential reasoning--for a judgment about a defendant's foresight are typically the materials for a judgment about his intention(s), his purpose(s). Focusing on his foresight will typically be a mere detour, neither necessary nor even helpful in determining whether or not he had a murderous purpose.'

${ }^{17} R v$ Powell [1999] 1 AC 1 (HL) 21 (Lord Hutton).
} 
what was then understood to be the law, namely the principles of PAL, which the Supreme Court, on appeal, however, held to have constituted a 'wrong turn' of the common law. ${ }^{18}$ It ordered a new trial at which $\mathrm{Mr}$ Jogee was found guilty of manslaughter rather than murder.

The foresight test, being the hallmark of PAL, had set the threshold for $\mathrm{Mr}$ Jogee's murder conviction comparatively low, for to convict Mr Hirsi, the actual killer, the common law required the prosecution to establish that he had acted with intent to kill or cause Mr Fyfe really serious injury. Foresight that his actions might lead to the one or other result was insufficient to satisfy the legal concept of intent for the actual murderer, while prior to the Supreme Court's decision in Jogee it sufficed to convict the accessory. Although lawyers are (intuitively) agreed that intent is a more stringent concept than foresight, the proper relationship between the two, and relatedly the essence of intent as a legal phenomenon, remains surprisingly elusive.

\section{FORESIGHT AS INTENTION VS FORESIGHT AS EVIDENCE OF INTENTION}

English law lacks a statutory definition for criminal intent. This means that, in traditional common law fashion, the legal meaning of intent has to be pieced together from reported cases. The relevant case law suggests that in instructing juries, judges are to follow the so-called 'golden rule': ${ }^{19}$ bearing in mind that intention is an ordinary English word, this requires lawyers to refrain from instructing jurors on the meaning of intention, unless absolutely necessary. Elaboration is only permissible (though in practice it is hardly ever given) where the defendant denies that he acted in order to kill or cause grievous bodily harm ('direct intent') but there is evidence to suggest that he must have foreseen death or grievous bodily harm ('oblique intent') to follow his or his companions' actions.

The 'golden rule' followed earlier judicial attempts to pin down the nature of 'oblique' intent. The challenge has been to carve out a legal concept that is neither overnor under-inclusive, in that it must neither invade the domain of recklessness (which is a less culpable mental state that turns on the unreasonable running of a foreseen risk), nor be so narrowly defined that it cannot accommodate illicit side-effects that were unsought but sure to materialise. Two opposing constructs pervade the relevant case

\footnotetext{
${ }^{18}$ Jogee (n 3) [82], [85], [87]

${ }^{19} R$ v Moloney [1985] AC 905 (HL) 926 (Lord Bridge).
} 
law, the aforementioned 'Inference' and 'Identity' Views. According to the 'Identity View', a defendant who foresees (to a specified degree of probability) that his action will cause death or serious injury intends such a result as a matter of legal definition; under the 'Inference View' intention is conceptually distinct from foresight, but this distinction notwithstanding a jury may infer intention from the fact that the accused foresaw death or serious harm as a virtually certain consequence of his conduct. ${ }^{20}$

These rival conceptions first came to prominence in the notorious case of Hyam where the Judicial Committee of the House of Lords (then the UK's highest Appellate Court) struggled to rationalise its narrow 3:2 decision to uphold a murder conviction against a defendant who had killed two children (without aiming to cause either of them death or serious injury) by setting fire to a dwelling. ${ }^{21}$ The decision, comprised of five individual opinions, adopts neither the 'Identity' nor the 'Inference' View; rather it oscillates between the two in a 'pick and mix' fashion. ${ }^{22}$ While much of the content of their Lordships' speeches is dedicated to working out the proper relationship between foresight and intention, three of the five Law Lords hearing the appeal also attempted to locate the evil of 'oblique' intent in the offender's mental attitude towards the results of her actions. Arguably, Jogee builds upon these attempts when linking intention with authorisation, a volitional concept that signals prior endorsement. In so doing, Jogee brings the legal intention debate, which started with Hyam, full circle. Over the next few pages, I will trace this development, looking at the key murder cases of Hyam, ${ }^{23}$ Moloney, ${ }^{24}$ Hancock and Shankland, ${ }^{25}$ Nedrick, ${ }^{26}$ and Woollin..${ }^{27}$

\section{Hyam [1975] AC 55}

The defendant, Mrs Hyam, was jealous of her former partner's new lover. In setting alight her rival's house, her self-proclaimed aim was to frighten the other woman into leaving the area. Tragically, her actions led to the death of her intended victim's young daughters. While Mrs Hyam admitted that she had appreciated the risk of causing harm to the house's occupants, she denied that she had wanted anyone to get hurt. She thus lacked intention in its core sense of aim, goal or purpose, and her liability for murder

\footnotetext{
${ }^{20}$ See generally Kaveny (n 13).

${ }^{21}$ Lord Diplock and Lord Kilbrandon dissented.

${ }^{22}$ Kaveny (n 13) 81.

${ }^{23} R v$ Hyam [1975] AC 55 (HL).

${ }^{24}$ Moloney (n 19).

${ }^{25} R v$ Hancock and Shankland [1986] AC 455 (HL).

${ }^{26} R v$ Nedrick [1986] 1 WLR 1025 (CA).

${ }^{27} R v$ Woollin [1999] 1 AC 82 (HL).
} 
depended on whether she had nevertheless acted with 'malice aforethought' (an archaic expression whose work is today done by 'intention'). ${ }^{28}$ In confirming her conviction by a bare majority, their Lordships answered this question in the affirmative. However, their individual opinions betray that there was no consensus on what murderous intent entailed outside the paradigm of acting in order to kill or cause serious bodily harm.

Lord Hailsham's opinion suggests, in large parts, that he supports the 'Inference View' of intention. As such, he rejects claims that foreseeing death or serious injury as highly probable was synonymous with intending such a consequence. ${ }^{29}$ Rather 'both the foresight and the degree of probability must be at least material which the jury may, and on occasion must, use as the basis on which an adverse inference is drawn as to the intention of the killer'. ${ }^{30}$ Other passages, however, suggest that for him the real impetus for upholding Mrs Hyam's murder conviction was the fact that she had caused the fatal consequences volitionally rather than with (a particular degree of) foresight. In a key passage of his judgment, Lord Hailsham concluded that murder required either:

(i) The intention to cause death; (ii) The intention to cause grievous bodily (...); (iii) Where the defendant knows that there is a serious risk that death or grievous bodily harm will ensue from his acts, and commits those acts deliberately and without lawful excuse, the intention to expose a potential victim to that risk as the result of those acts. (...) Without an intention of one of these three types the mere fact that the defendant's conduct is done in the knowledge that grievous bodily harm is likely or highly likely to ensue from his conduct is not by itself enough to convert a homicide into the crime of murder. ${ }^{31}$

On this account, Mrs Hyam's case falls squarely within (iii): while she realised that her actions would put the occupants of the house in grave danger, what made her mind guilty to a sufficient degree to warrant a murder conviction was not her appreciation of the risk as such, but the fact that she went on to embrace that risk. ${ }^{32}$ Indeed, without creating real danger for the occupants, the message she wished to send her rival would not have been as strong; thus, although it is true that she did not wish to hurt anyone, she still wanted to put them at risk of serious harm. ${ }^{33}$ Having exploited

\footnotetext{
${ }^{28}$ The term is a double-misnomer, for 'malice aforethought' requires neither ill-will nor premeditation.

${ }^{29}$ Hyam (n 23) 77.

${ }^{30}$ ibid 68.

31 ibid 79.

32 Pedain (n 12) 588.

${ }^{33}$ Kaveny (n 13) 99.
} 
the risk for her own purposes (as opposed to simply running it), she must not be allowed to distance herself from its fatal consequences. ${ }^{34}$ Her state of mind was more blameworthy than that of a reckless person who, having appreciated that there is a risk of harm, unreasonably decides to take it: Mrs Hyam was not just taking risks she ought not to have taken; the creation of danger was central to her goal of teaching her rival a lesson.

'Oblique' intention as underpinned by will rather than cognitive processes also features prominently in the 'guilty mind' accounts given by the two dissenting Law Lords (who would have allowed Mrs Hyam's appeal). Thus, Lord Diplock opined that no distinction is to be drawn in English law between the state of mind of one who does an act because he desires it to produce a particular evil consequence, and the state of mind of one who does the act knowing full well that it is likely to produce that consequence... What is common to both these states of mind is willingness to produce the particular evil consequence: and this, in my view, is the mens rea needed to satisfy a requirement ... that ... he must have acted with “intent" .... (on p. 86, emphasis added).

On this account, both the direct and 'oblique' types of intent are underpinned (albeit to differing degrees of intensity) by the defendant's readiness to generate the proscribed consequence (if only to realise some ulterior aim). Note that, in Lord Diplock's view, such readiness is already present where the defendant appreciates that the proscribed consequence is likely, though not necessarily sure, to follow. Since the facts suggest that Mrs Hyam foresaw serious harm as likely, it needs pointing out that Lord Diplock would have allowed her appeal this fact notwithstanding, because he advocated restricting the scope of murder to cases where the defendant demonstrated a readiness to cause death (as opposed to grievous bodily harm). ${ }^{35}$ In similar vein, the other dissenter, Lord Kilbrandon, would have allowed Mrs Hyam's appeal because in his view, absent an intention to kill, murder, lest it be overly broad, ought to require that

\footnotetext{
${ }^{34}$ Pedain (n 12) 587-588, 593. A similar position is defended by Alan Norrie, 'Oblique Intention and Legal Politics' (1989) Crim LR 793, 796 who argues that the legal definition of intention can be squared with a common-sense definition which is based on a broader understanding of what it means to desire: 'Where I intend to bring $\mathrm{X}$ about and am sure that $\mathrm{Y}$ is a necessary corollary, but it turns out that $\mathrm{X}$ happens without Y, I have failed to produce the necessary corollary but not failed in my intention. (...) $\mathrm{Y}$ was part of my intention in that I was prepared to accept its necessity as a means to my end or as a sideconsequence of it. I may not directly have wanted $Y$ to happen, but I wanted X sufficiently to will the existence of $\mathrm{Y}$ too. I may be quite happy that $\mathrm{X}$ occurs without $\mathrm{Y}$, but that does not mean to say the bringing about of $\mathrm{Y}$ was not part of my initial intention.'

${ }^{35}$ Hyam (n 23) 86-87.
} 
'the jury must be satisfied ... that the accused knew that death was a likely consequence of the act and was indifferent whether that consequence followed or not. ${ }^{36}$

The remaining speeches were not so clear on the role of volition, if any, within the concept of 'oblique' intent. Lord Cross's account (who along with Lord Hailsham and Viscount Dilhorn formed the majority confirming Mrs Hyam's conviction) was in the main concerned with working out the relationship between foresight and intention - on which he declined to take a definitive stance. He looked at the issue from two perspectives: that of the ordinary man, and that of a 'logician'. ${ }^{37}$ From the ordinary man's perspective, he explained, it did not matter whether a consequence was foreseen or intended in the strict sense of the word:

If, for example, someone parks a car in a city street with a time bomb in it which explodes and injures a number of people I think that the ordinary man might well argue as follows: "The man responsible for this outrage did not injure these people unintentionally; he injured them intentionally. So he can fairly be said to have intentionally injured them - that is to say, to have intended to injure them. The fact that he was not certain that anyone would be injured is quite irrelevant (...) it was a matter of indifference to him whether they were injured or not. ${ }^{38}$

On the other hand, 'a logician might object that the ordinary man was using the word "intention" with two different shades of meaning', so that 'as a matter of the correct use of language the man in question did not intend to injure those who were in fact injured'. ${ }^{39}$ In the end, Lord Cross saw no need to decide the issue, as 'the doing of an act which one realises may well cause grievous bodily harm should also constitute malice aforethought whether or not one realises that one's act may endanger life.' 40 Why this should be so he did not say, however.

Viscount Dilhorn also preferred to sit on the fence. His support for Mrs Hyam's conviction was ultimately based on the longevity of the 'oblique' intent doctrine:

Whether or not it be that the doing of the act with the knowledge that certain consequences are highly probable is to be treated as establishing the intent to bring about those consequences, I think it is clear that for at least 100 years such knowledge has been recognised as amounting to malice aforethought (p. 82).

\footnotetext{
36 ibid 98 (emphasis added).

${ }^{37}$ ibid 96.

38 ibid.

39 ibid.

40 ibid.
} 
It was unfortunate, then, that in Hyam, the Law Lords did not give an unequivocal, nor indeed a univocal, answer to the question of the relationship between foresight and intention. The underlying assumption was that the issue did not really require resolution as long as most of them agreed that foresight of serious harm as probable was sufficient to satisfy the requirements of malice aforethought. This contributed towards a development whereby the volitional element in intention (as exposed by Lords Hailsham, Diplock, and Kilbrandon) took a back seat in the legal discourse, in favour of the cognitive component of foresight: later cases did not take up the ideas of wilfully exposing someone to a risk of death or serious injury or indifference towards such an outcome, nor the notion of a willingness to produce the evil consequence, choosing instead to focus on what the defendant foresaw. Rather, the legal debate on intent became fixated, first, on the merits of adopting an 'Inference' versus 'Identity' approach, and secondly, on specifying the minimum degree of foresight sufficient to support the conclusion that the accused had acted with murderous intent: need he have foreseen death or serious harm as probable, highly likely or almost certain?

\section{Moloney [1985] AC 905}

The first case after Hyam to consider these issues was Moloney. A drunken contest between a father and son to determine who was quicker on the draw had tragically resulted in the son shooting his father. Unfortunately, Lord Bridge, who gave the leading judgment, remained ambiguous as to the proper relationship between foresight and intention. On the one hand, he suggested that juries should be invited to consider whether 'death or really serious injury (...) [was] a natural consequence of the defendant's voluntary act' and whether 'the defendant [foresaw] that consequence as being a natural consequence of his act'. If he did, 'it is a proper inference for [the jury] to draw that he intended that consequence'. ${ }^{41}$ On the other, 'the probability of the consequence taken to have been foreseen must be little short of overwhelming before it will suffice to establish the necessary intent,${ }^{42}$ These statements proved problematic in two ways: first, they left unclear whether foresight by definition amounted to intention or whether it was just evidence from which a jury could deduce that the defendant had acted with intent. If the latter, there would remain a margin of discretion for the jury who, in drawing or rejecting inferences, would be asked to make a judgment

\footnotetext{
${ }^{41}$ Moloney (n 19) 929.

42 ibid 925.
} 
call. Secondly, Lord Bridge's speech remained unclear on the question of probabilities: is a 'natural' consequence one that is likely, highly likely or almost certain to occur?

\section{Hancock and Shankland [1986] AC 455}

The subsequent case of Hancock and Shankland (concerning the liability of two striking miners who had, without meaning to, killed a taxi driver by throwing a piece of concrete from a bridge, in an attempt to prevent working miners from travelling to work) attempted to clarify these matters. It came down in favour of the 'Inference View', with Lord Scarman suggesting:

if the likelihood that death or serious injury will result is high, the probability of that result may ... be seen as overwhelming evidence of the existence of the intent to kill or injure. ... [Juries] require an explanation that the greater the probability of a consequence the more likely it is that the consequence was foreseen and that if that consequence was foreseen the greater the probability is that that consequence was also intended. But juries also require to be reminded that the decision is theirs to be reached upon a consideration of all the evidence. ${ }^{43}$

As this quote makes clear, Hancock favoured a 'sliding scale of probabilities' approach to the inference of intention from foresight: the higher the probability that the proscribed outcome would occur, the more likely that the defendant foresaw it, and therefore intended it. As we will see, a similar approach is now supported by the Supreme Court in Jogee in the context of accessorial liability for murder, albeit that in Jogee, the sliding scale is framed in terms of the strength of the evidence ("if D2 continues to participate in crime A with foresight that D1 may commit crime $\mathrm{B}$, that is evidence, and sometimes powerful evidence, of an intent to assist D1 in crime B'), ${ }^{44}$ rather than in degrees of probabilities (that the outcome would occur).

\section{Nedrick [1986] 1 WLR 1025}

Further support for the 'Inference View' came from the Court of Appeal in Nedrick (the facts of which were similar to Hyam in that the defendant had caused death by torching a house without meaning to kill or injure its occupants). By the time this appeal came to be decided, it was widely accepted that the threshold for murder had been set too low in Hyam. Against this backdrop, the Court of Appeal proposed that juries be instructed 'that they are not entitled to infer the necessary intention, unless they feel sure that

\footnotetext{
${ }^{43}$ Hancock and Shankland (n 25) 473 (Lord Scarman, emphasis added).

${ }^{44}$ Jogee (n 3) [66].
} 
death or serious bodily harm was a virtual certainty (barring some unforeseen intervention) as a result of the defendant's actions and that the defendant appreciated that such was the case'. ${ }^{45}$

\section{Woollin [1999] 1 AC 82}

Then came Woollin, which is still the leading case on murder and 'oblique' intent. This was an appeal against conviction brought by a father who, in a fit of anger and without meaning to seriously injure, had caused his infant's death by throwing him onto a hard surface. Inspired by academic criticisms that the word 'infer' in the jury model direction in Nedrick might confuse jurors, Lord Steyn, who gave the leading judgment, altered the model guidance to the effect that jurors are 'not entitled to find' that the defendant acted with murderous intent unless death or serious harm was a virtual certainty and the defendant had appreciated that such was the case. ${ }^{46}$ (p. 96).

The modified 'virtual certainty' test gave the 'Identity View' a new lease of life: several commentators understood Lord Steyn to be saying that the connection between virtual certainty and intention was not just evidential. ${ }^{47}$ Indeed, at one point in Woollin Lord Steyn himself observed that 'the effect of the critical direction [in Nedrick] is that a result foreseen as virtually certain is an intended result' ${ }^{48}$ Further support for the 'Identity View' could be drawn from Lord Steyn's admission that he had opted to substitute 'infer' with 'find' in response to academic criticisms. Amongst these is a commentary by Glanville Williams who wrote: ${ }^{49}$

The only thing wrong with [the Nedrick formulation] ... is the use of 'infer'. ... An intelligent jury may be fogged at being told that they can infer $\mathrm{x}$, when they are not told what $\mathrm{x}$ is (but only what it is not). The proper view is that intention in its wider sense includes not only desire of consequence (purpose) but also foresight of the certainty of the consequence, as a matter of legal definition. What the jury infer from the facts is the defendant's direct intention or foresight of a consequence as certain; there is no additional element to be 'inferred.'

\footnotetext{
${ }^{45}$ Nedrick (n 26) 1028 (Lord Lane CJ, emphasis added).

${ }^{46}$ Woollin (n 27) 96.

${ }^{47}$ AP Simester 'Case Comment: Murder, mens rea, and the House of Lords - again' (1999) 115 LQR 17, 19- 20.

${ }^{48}$ Woollin (n 27) 93 (emphasis added).

${ }^{49}$ Glanville Williams, 'The mens rea for Murder: leave it alone' (1989) 105 LQR 387-397.
} 
Williams here clearly advocates the 'Identity View' of intention (as indeed he had done since at least the 1950s). ${ }^{50}$ On the other hand, even under Woollin as amended, jurors remain only 'entitled" 51 to find intent if the threshold condition of virtual certainty is met. Supporters of the 'Inference View' were quick to point out that the use of permissive language ('entitled') suggests that the Woollin model direction is still no more than an evidential proposition under which it remains open to the jury to reject a finding of intent. ${ }^{52}$

This, the 'Inference' reading of Woollin, has been endorsed by the Court of Appeal in the case of Matthews and Alleyne. ${ }^{53}$ Rix LJ stated:

In our judgment, however, the law has not yet reached a definition of intent in murder in terms of appreciation of a virtual certainty (...) [W]e do not regard Woollin as yet reaching or laying down a substantive rule of law. On the contrary, it is clear from the discussion in Woollin as a whole that Nedrick was derived from the existing law, at that time ending in Moloney and Hancock, and that the critical direction in Nedrick was approved, subject to the change of one word. (...) Having said that, however, we think that, once what is required is an appreciation of virtual certainty of death, and not some lesser foresight of merely probable consequences, there is very little to choose between a rule of evidence and one of substantive law. ${ }^{54}$

Whether this is indeed the interpretation most true to Lord Steyn's opinion in Woollin, the scales of justice thus came down in favour of the 'Inference View'.

\section{MURDER BY PERPETRATION VS MURDER BY COMPLICITY}

However, support for the 'Inference view' has not been consistent. The conflict between 'Identity' and 'Inference' view persisted elsewhere, for, remarkably, whilst the judiciary adopted the 'Inference View' in the context of murder and principal offenders (i.e. those who caused death, or 'murder by perpetration'), the 'Identity View' prevailed in a related line of cases, concerning the liability for murder of accessories (i.e. those who assisted or encouraged those causing death, or 'murder by complicity'). The

\footnotetext{
${ }^{50}$ See eg Glanville Williams (ed), Salmond on Jurisprudence ( $11^{\text {th }}$ edn, Sweet \& Maxwell 1957) 412.

${ }^{51}$ Woollin (n 27) 96.

${ }^{52}$ Alan Norrie, ‘After Woollin' [1999] Crim LR 532, 537.

${ }^{53}$ Matthews and Alleyne [2003] EWCA Crim 192, [2003] 2 Cr App R 30.

54 ibid [43].
} 
leading cases are Powell ${ }^{55}$ (decided shortly before Woollin), as well as Rahman ${ }^{56}$ and Gnango $^{57}$ (both of which postdate Woollin).

The appellants in Powell had been convicted for their involvement in the murder of a drug dealer. The latter had been shot by a group of three men (which included the two appellants), but the prosecution could not establish who of the three had pulled the trigger. The appellants had been prosecuted on the basis of PAL: even if neither of them had been the gunman, they must have foreseen the possibility that whoever had the gun might use it intentionally to inflict serious injury. In dismissing their appeal, Lord Steyn (who not long thereafter would give the lead judgment in Woollin) asserted that such 'foresight is a necessary and sufficient ground of the liability of accessories' ${ }^{58}$ Calling it a sufficient ground of liability left little room for doubt that his Lordship perceived of foresight as being capable without more of fixing the defendant with liability. Indeed, in the context of PAL, foresight that the principal offender might go on to cause the victim death or serious injury was henceforth taken to establish the accessory's guilty mind by definition ('Identity View'), without the need to draw any inferences as to what the latter had intended.

Powell (which was handed down on 30 October 1997) pre-dated the decision in Woollin (handed down on 22 July 1998), if only by nine months. Lord Steyn heard both appeals (the only Law Lord to do so) and on both occasions he gave influential speeches. Curiously, within a mere matter of months, he seems to endorse both the 'Inference View' of intention (Woollin) and the 'Identity View' (Powell). While it is, of course, possible that in between deciding Powell and Woollin, he came around to the 'Inference View', it is also conceivable that, as a matter of interpretation, post-Woollin case law got it wrong and that Lord Steyn had in fact been speaking in support of the 'Identity View' on both occasions. After all, the 'Identity View' was at the time strongly supported by leading academics, ${ }^{59}$ whose work Lord Steyn referred to approvingly at various points in his judgment on Woollin.

Having said that, the prevalence of foresight as the mental element in PAL was subsequently affirmed at the highest judicial level both in Rahman and Gnango ${ }^{60}$ (the

\footnotetext{
${ }^{55}$ Powell (n 17).

${ }^{56} R v$ Rahman [2008] UKHL 45, [2009] 1 AC 129.

${ }^{57} R v$ Gnango [2011] UKSC 59, [2012] 1 AC 827.

${ }^{58}$ Powell (n 17) 13.

${ }^{59}$ See (n 49), (n 50) and accompanying text.

${ }^{60}$ There is some limited discussion of Woollin (n 27) in Gnango (n 57) by one of the five Justices hearing the appeal: Lord Dyson JSC (at [125]) suggested that 'oblique' intent to aid and abet was also subject to
} 
facts of which do not need concern us here), thereby perpetuating the anomalies in the way the 'guilty mind' was assessed for murderers and their accessories respectively. This remained so until in February 2016 Jogee rejected PAL as a 'wrong turn' of the common law and, crucially, with it, the 'Identity View'. In the Supreme Court's words: 'The error was to equate foresight with intent to assist, as a matter of law; the correct approach is to treat it as evidence of intent. The long-standing pre [-PAL] practice of inferring intent to assist from a common criminal purpose which includes the further crime, if the occasion for it were to arise, was always a legitimate one; what was illegitimate was to treat foresight as an inevitable yardstick of common purpose. ${ }^{61}$ This is an unequivocal endorsement of the 'Inference View'.

\section{E. INCONSISTENT THRESHOLD CONDITIONS: PERPETRATION VS COMPLICITY}

What then about the other contended matter, the issue of probability? It is here that Woollin and Jogee part ways: as we saw, under Woollin, jurors are not permitted to conclude that the perpetrator of a murder acted with 'oblique' intent unless they believe that he had appreciated that death or grievous bodily harm was a virtually certain consequence of his actions. By contrast, there is no mention in Jogee of a threshold condition to curtail the jury's ability to infer that the accessory intended to assist murder from evidence that he anticipated the principal's actions. Jogee, in other words, leaves open the possibility that the jury might draw the requisite inference on the basis of evidence that the accessory foresaw that his conduct might support a murder with less than virtual certainty.

The omission of a threshold condition is unlikely to be the result of an oversight: the defence for Mr Jogee had invited the Supreme Court to rule that PAL ought to require the defendant to have foreseen the prohibited consequences as probable rather than just possible. ${ }^{62}$ It is therefore plausible that the Justices deciding Jogee preferred an unencumbered version of the 'Inference View', such as arguably had governed the

\footnotetext{
the Woollin threshold condition. Gnango is a difficult decision, however; it is notorious amongst lawyers for lacking a clear ratio: although there was consensus as to the outcome, the five Justices disagreed on what basis the conviction was to be upheld (ie whether the basis was PAL, aiding and abetting or joint perpetration).

${ }^{61}$ Jogee (n 3) [87] (emphasis added).

${ }^{62}$ The certified question asked whether the prosecution needed to prove that a secondary party, who encouraged the primary offender to commit some harm, foresaw the primary offender's acquisition and use of a weapon for murder as 'probable' rather than 'possible' for PAL to apply.
} 
law of murder up until Nedrick/Woollin and which assessed the evidential strength of foresight under a sliding scale of probability approach, while stressing that foresight was only ever one factor to be taken into account.

English criminal law now faces the following dilemma: as long as Woollin remains good law in murder generally, Jogee cannot achieve what it set out to achieve, namely to restore parity of culpability between principal offender and accessory: ${ }^{63}$ if in deciding the fate of secondary parties juries are allowed to draw inferences (as to an intention to assist or encourage murder) from evidence of foresight in any degree, including, therefore, possibility, whereas they must not do so in the case of perpetrators unless death or serious injury was (foreseen as) virtually certain to occur, it will still remain easier to prosecute accessories for murder than their principals.

How can this problem be solved? It is, of course, open to any legal system to fashion context-specific thresholds for criminal liability: one rule for the perpetrators of murder, another for their accessories. But distinguishing cases in this way is both unsatisfactory (because it has the potential to treat the individual more leniently who, in most cases, deserves greater condemnation, i.e. the actual killer) and unrealistic: while Lord Steyn famously prefaced his decision in Woollin by remarking that intention does not necessarily have the same meaning in every context of the criminal law, ${ }^{64}$ in practice the approach taken in the murder context has been applied to crimes of intent generally. Often, it will not even be clear whether a particular defendant acted as principal or accessory; asking jurors to consider such a person's case in the alternative with different tests for determining 'oblique' intent depending on whether they consider his liability under the principal offender or accessory routes might prove confusing. ${ }^{65}$ More importantly (for our purposes of analysing intent as a legal phenomenon), drawing such a distinction is conceptually flawed, in that it relies on competing accounts of what it means (obliquely) 'to intend' something in the legal sense.

Should we therefore read the Woollin direction into Jogee? This approach has found favour with some commentators who point out that in ordinary accessory liability, the intention to assist or encourage has traditionally been thought to be

\footnotetext{
${ }^{63}$ Whether parity of culpability can, and indeed, should be achieved is another matter.

${ }^{64}$ Woollin (n 27) 90.

${ }^{65}$ David Ormerod \& Karl Laird, 'Jogee: not the end of a legal saga but the start of one?' (2016) Crim LR 539, 546-548.
} 
governed by Woollin also. ${ }^{66}$ Sticking with this time-honoured approach would constitute a principled solution to the issue. On the other hand, one might object that delimiting the jury's ability to draw inferences seems to go against the very spirit of the Jogee decision which puts great trust in the jury as fact-finders of the mental state.

Perhaps the best solution is to let Jogee prevail over Woollin: the model jury direction is so rarely used in practice that it might as well be ignored, while conversely its significance is probably overstated in academia. But putting Woollin to rest requires us to trust lay juries to make the right judgement calls. While Jogee seems content to do so, the 'murder by perpetration' line of case law raises concerns about a blurring of lines between intention and recklessness. Broadly speaking, recklessness as a legal concept involves the conscious taking of an unjustified or unreasonable risk. As with intent, its essence is notoriously difficult to pin down, however, and the case law offers varying accounts of what it means to be reckless. Frequently recklessness, in parallel to intention, is explained with reference to degrees of foresight: it follows logically from Woollin that a consequence foreseen with less than virtual certainty has been caused recklessly. So if, on one account at least, the crucial line between intention and recklessness is to be drawn on the basis of shades of foresight, how are we to distinguish between the two if that 'threshold condition' goes out the window? What, in other words, should replaces the Woollin test of virtual certainty?

\section{F. INTENTION AS 'AUTHORISATION' OR ENDORSEMENT}

It is here that we return to ideas of volition. In his case note on Woollin, Alan Norrie has argued that the flaw with the cognitive conception of oblique intent lies in its failure 'to deal with the underlying issue of the accused's moral commitment to the result she brings about. ${ }^{67}$ Jogee, I would argue, picks up on this (as did Hyam before it), if only in passing: in a key passage criticising Chan Wing Siu (the Privy Council decision said to be the origin of PAL), the accessory's intention to assist or encourage the perpetrator to commit the principal offence is associated with authorisation:

There can be no doubt that if D2 continues to participate in crime A with foresight that D1 may commit crime $\mathrm{B}$, that is evidence, and sometimes

\footnotetext{
${ }^{66}$ AP Simester, 'Accessory liability and common unlawful purposes' (2017) 133 LQR 73, 84: 'In order to intend "to assist $\mathrm{P}$ to commit a burglary", $\mathrm{S}$ must either act in order to assist $\mathrm{P}$ to commit a burglary (i.e. because for some reason $\mathrm{S}$ has an interest in P's committing it), or act in the practical certainty that his or her conduct will assist P to commit a burglary. Will, not may.'

${ }^{67}$ Alan Norrie, ‘After Woollin' [1999] Crim LR 532, 541-542.
} 
powerful evidence, of an intent to assist D1 in crime B. But it is evidence of such intent (or, if one likes, of "authorisation"), not conclusive of it. ${ }^{68}$

I would argue that this passage contains not just an unambiguous endorsement of the 'Inference View' of intent; it also offers a rationalisation of intent in terms of authorisation. ${ }^{69}$

In everyday language, authorisation denotes agreement or assent. Linking intent with authorisation in the context of criminal complicity thus suggests that the Supreme Court perceives of the accessory's liability as being grounded in approval: the accessory becomes complicit in the principal's offence not just because his actions support it, but because he has morally committed to it, in the sense that he has given the deed his 'blessing'. ${ }^{70}$

Interestingly, this is not the first time authorisation has featured in the law of complicity (although the way it is employed to support accessorial liability has changed, as I will explain below): before Jogee, authorisation was occasionally drawn upon to justify PAL. Indeed, the clearest statement to this effect is found in the very Privy Council decision that was (in rather strong terms!) disapproved of in Jogee:

That there is [a principle of PAL] is not in doubt. It turns on ... authorisation, which may be express but is more usually implied. It meets the case of a crime foreseen as a possible incident of the common unlawful enterprise. The criminal culpability lies in participating in the venture with that foresight. ${ }^{71}$

In this statement, the accessory's continued participation in the original criminal enterprise is taken as assent to any crime foreseen as a possible incident of that venture. A similar explanation is still put forward by jurisdictions that have chosen, post-Jogee, (for reasons beyond the scope of this paper) to retain their variants of PAL.

The argument is outwardly attractive, but in the context of PAL any justification that hinges on assent (or related concepts) must ultimately fail. This is because authorisation runs into insurmountable difficulties where the perpetrator's crime was

\footnotetext{
${ }^{68}$ Jogee (n 3) [65]-[66].

69 The importance of 'authorisation' is underlined by the following passage in the latest edition of Archbold: Criminal Pleading, Evidence and Practice (Sweet \& Maxwell 2018) § 18-15: 'Where two or more persons embark on a joint enterprise each is liable for the acts done in pursuance of that joint enterprise. That includes liability for unusual consequences if they arise from the execution of the agreed joint enterprise. However, if a participant in the venture goes beyond what has been tacitly agreed as part of the common enterprise, the other participants are not liable for the consequences of that unauthorised act. It is for the jury to decide whether what was done was part of the joint enterprise or was or may have been an unauthorised act and therefore outside the scope of the joint enterprise'.

${ }^{70}$ I have borrowed this expression from Pedain (n 12) 589.

${ }^{71}$ Chan Wing-Siu [1985] AC 168 (PC) 175 (Sir Robin Cooke, emphasis added)
} 
not in any sense of the word embraced by the accessory. The quote from Chan Wing Siu suggests that we can unfailingly infer authorisation from an accessory's continued participation in the enterprise. But continued participation is no proxy for assent; without an inkling of what goes through the defendant's mind, the naked, observable fact that he failed to distance himself from a criminal enterprise (aimed at committing an offence A) once he realised that another offence B (often murder) was on the cards is not conclusive. Nor is such an approach consistent with how PAL has been applied in practice: in England, the doctrine could be used to impose liability on accessories who had made their objections to crime B perfectly known to the principal offender prior to its commission. ${ }^{72}$ Of course, actions do at times speak louder than words, sufficiently so that we may doubt someone's self-proclaimed lack of commitment to crime B. But even then should we take a closer look, lest we misinterpret the actor's true objectives. As the Supreme Court stressed: '[I]f D2 continues to participate in crime A with foresight that D1 may commit crime B, that is evidence, and sometimes powerful evidence, of an intent to assist D1 in crime B. But it is evidence of such intent ... not conclusive of it. ${ }^{973}$

Realistically, most situations allow for more than one interpretation. In the case of 'continued participation' in a criminal enterprise aimed to bring about a non-fatal offence $\mathrm{A}$, there could be a number of reasons why an accessory did not withdraw from this after he realised that there was a chance murder would be committed. At one end of the spectrum, he may have stayed put because murder was precisely what he was after. At the other end, he might have held a genuine, if naïve, belief that his continued participation would have a moderating influence on his companions, making it in fact less likely that murder would occur incidentally to whatever other crime (eg burglary) was at the heart of their original joint criminal venture.

While Jogee is rightly critical of Chan Wing Siu and the way this decision has employed the language of authorisation to justify the indiscriminate imposition of farreaching PAL (going beyond cases where the accessory's decision to continue with the enterprise could have been construed reasonably as a ratification of any incidental crime), Jogee suggests that a concept of authorisation that is true to its everyday

\footnotetext{
${ }^{72}$ See Lord Mustill in Powell (n 17) 11: 'How can a jury be directed at the same time that S is guilty only if he was party to an express or tacit agreement to do the act in question, and that he is guilty if he not only disagreed with it, but made his disagreement perfectly clear to P? Are not the two assertions incompatible?'

${ }^{73}$ Jogee (n 3) [66] (emphasis added).
} 
meaning can help delineating criminal liability: if you gave crime B your blessing, then you will have to answer for it. Conversely, you will not have to answer for crime B unless you gave its commission your blessing. Unfortunately, the Supreme Court does not really discuss authorisation in any detail - it simply assumes that it is congruent with intention. But, as we saw above, this remains controversial. However, the only interpretation of intent that can satisfactorily replace Woollin is one involving volition, and this, of course, resonates with the everyday meaning of authorisation.

Yet we might query whether authorisation (as a legal term of art) is sufficiently versatile to flesh out the idea of criminal intents across a range of offences and settings. As we have seen, one persistent problem with the law of intention was the inconsistent way in which 'oblique' intents were conceptualised in the related contexts of murder by perpetration and murder by complicity. If we are looking for a way to unify our approaches to assessing intention in both contexts, then authorisation is a less than ideal candidate, for the language of 'authorisation' pre-supposes two parties, one to authorise and one to be authorised. The term is thus ill-suited to govern the sole offender context (murder by perpetration). Linguistically, it does not make much sense, either, to say that an individual has authorised the consequences of his actions: I can only authorise that which I have a right to authorise, and I do not have a right to commit a crime. ${ }^{74}$ However, a natural way to express the intended idea would be to say that I have endorsed the consequences of my actions. Endorsement might thus be a better term to use. $^{75}$

There is further merit to the idea of endorsement. While I have just suggested that the term lends itself naturally to describing what is going on when we say about someone that he 'obliquely' (or indirectly) intended to commit murder or obliquely intended to assist murder, endorsement can also explain the paradigm of intention: what stronger way to endorse (the outcome of) one's actions than to set out to achieve them with purpose? Applied in this way, endorsement has unifying merits beyond the sole offender and complicity contexts: it can serve as a 'common denominator' 76 informing both the direct and oblique variants of intent.

\footnotetext{
${ }^{74}$ The language is plainly borrowed from the civil law concept of agency, where, in the paradigm case, the principal authorises the agent to enter into a contract on the principal's behalf. But here the principal would be perfectly entitled to enter into the contract herself - it would make no sense, for example, for a principal to 'authorise' the agent to sell a picture belonging to (and in the possession of) a third party something which the principal has no right to authorise.

${ }^{75}$ See also Pedain (n 12) 585 ('intention as endorsement').

76 ibid 586.
} 
Antje Pedain, writing in the murder and principal offender context, has persuasively argued that understanding intention as underpinned by endorsement would do away with the need to consider degrees:

[i]f intending something means to endorse it as the consequence of one's voluntary actions, then the issue is not about whether you endorse it as the certain, the likely, or the unlikely consequence of your behaviour. It is about endorsement as such. The point is whether you give that consequence your blessing. ${ }^{77}$

This is a point well taken. But I would argue that we cannot part with gradations altogether, for under the 'endorsement' approach to intention, direct and 'oblique' intent would still seem to be placed on opposite ends of a spectrum of volition (which is the strongest where the proscribed consequence is desired, or directly intended). The problem is where to draw the line at the other end of the spectrum (where a consequence is 'obliquely' intended or 'just about endorsed'): at what point should the jury decide that the minimum condition for criminal intent, endorsement, is present? Are we looking for affirmative assent or will reluctant acquiescence do ${ }^{78}$ It is clear that the endorsement approach will need fine-tuning, if it is to help us delineate (as opposed to merely explain) liability for crimes of intent. It is here that (legal) philosophers might assist us lawyers in working out the proper contours of a new conception for the common law notion of intent. Jogee has taken a first (tentative) step towards a volitionbased understanding of 'oblique' intent, but the idea of endorsement needs sharpening, lest similar ambiguities on the volitional level as have bedevilled the law under the ruling cognitive conception get in the way of developing an approach that properly demarcates the (legal) domain of intent.

\section{G. CONCLUSION}

Intent as a legal phenomenon has proved surprisingly elusive. Outside the paradigm purpose, goal or aim, judicial attempts to encapsulate the essence of what it means to

\footnotetext{
77 ibid 589.

${ }^{78}$ A parallel might perhaps be drawn to the law of consent as applies in the context of the Sexual Offences Act 2003. Here it is accepted that consent covers 'a wide spectrum of states of mind'; the jury is frequently asked to draw the line between real consent on the one hand and mere submission on the other, 'applying their combined good sense, experience and knowledge of human nature and modern behavior to all the relevant facts', see $R$ v Ali [2015] EWCA Crim 1279, [2015] 2 Cr App R 33 [59], citing Olugboja [1982] QB 320 (CA). The outer limits of the concept of consent thus appear to be reluctant, but genuine, acquiescence versus acquiescence that is no more than mere submission.
} 
intend a particular consequence have generally focussed on the degree with which the accused foresaw the consequence occurring. Since the decision in Woollin, the orthodox view has been that for a consequence to be intended, absent a wish to bring it about, it must have been foreseen by the accused himself as virtually certain to result from his chosen course of conduct. Whether such an understanding of 'oblique' intent amounts to a substantive definition of criminal intent (the so-called 'Identity View') or just a rule of evidence allowing intent to be inferred from foresight in a specified degree ('Inference View') has long since been subject to (legal) debate.

The case law can be seen to oscillate between the two approaches. Surprisingly, while the judiciary eventually, after a period of ambiguity, came down in favour of the 'Inference View' in the context of murder and principal offenders, it let the 'Identity View' prevail in the related context of complicity to murder, until 2016, when this approach was rejected in favour of the 'Inference View' by the UKSC in Jogee.

Jogee determined that foresight of a consequence does not in itself establish an accessory's criminal mind; it is merely evidence from which an inference to the requisite intent might be drawn. In so holding, the decision has brought the law of criminal complicity back in line with the general law of murder. In both contexts, foresight is now treated as evidence of intention rather than as intention itself.

Some differences persist, however. Unlike oblique intent in the principal offender context (where the jury is not entitled to find oblique intent unless sure that death or serious injury was a virtually certain consequence of the perpetrator's acts and he appreciated as much), Jogee does not impose a threshold condition for the liability of accessories. In the complicity context, then, a jury appears to be entitled to infer intention (to assist or encourage murder) from evidence of foresight in whichever degree. It follows that intention is still more easily made out in the latter context, making it easier to convict accessories of murder than their principal offenders.

A way out of this conundrum would be to replace the cognitive threshold condition of 'virtual foresight' with a volitional concept. In a key paragraph of the judgment in Jogee, the Supreme Court (albeit fleetingly) associates the accessory's intention to assist or encourage the principal offender to commit the principal offence with authorisation. As this paper has sought to demonstrate, this concept, with its connotations of assent or approval, could be utilised to flesh out the idea of oblique intent. 'Endorsement' would be a preferable term to use, however, as it is more versatile: in contrast to 'authorisation', which presupposes a two-party context, it is 
possible to endorse the actions and consequences brought about by others as well as the consequences of one's own actions. It also fits in with the case law: while the idea of endorsement (albeit framed in terms of 'authorisation') is supported in Jogee, there is also at least one pre-Woollin murder case, Hyam, that attempted to locate the evil in oblique intent in the defendant's attitude towards the foreseen consequences of her actions.

Endorsement has further unifying merits. The core concept of intention - a consequence brought about purposively - can also be explained with reference to this concept, for what clearer way to endorse a consequence than to set out to bring it about? The concept would also allow us to simplify the law: the traditional approach has never been able to explain the relationship between direct and oblique intent. Are there two independent, though related, concepts ('Identity View') or is one a sub-category of the other ('Inference View')? If both can be put on the same footing, we will end up with just one concept of intent that is underpinned by ideas of endorsement on a spectrum.

While the higher end of this spectrum is clearly demarcated (direct intent $=$ purpose or aim), there remains a question mark as to where we should draw the line at the lower end. In other words, when should we say about a consequence that it was sufficiently endorsed (and therefore intended)? Where is the dividing line between intention and recklessness to be (re-)drawn? It is here that philosophers might help lawyers in working out the proper contours of the concept. Jogee has opened the door for a new unified conception of intent that is built around (degrees of) volition, rather than two conceptually distinct types of intent, one of which is volitional and the other cognitive in nature. Now we need to flesh out the new conception and determine its limits. 
Oblique Intent, Foresight and Authorisation 